\title{
Ventricular function in Chagas' heart disease
}

\author{
Division of Cardiology, Department of Internal Medicine, Faculdade de Medicina de \\ Ribeirão Preto, Universidade de São Paulo - São Paulo, Brazil
}

Invasive and noninvasive methods used to evaluate ventricular function in Chagas's disease are reviewed. The traditional indices of overall ventricular performance reflect the interaction of preload, contractility, afterload and heart rate. Therefore, they are unable to distinguish changes in contractility from modifications of loading conditions. The role of ventricular function as a predictor of mortality in chronic Chagas' heart disease is discussed. Ventricular function abnormalities in patients with indeterminate and digestive forms of Chagas' disease are especially emphasized. Finally, the evidence of early impairment of diastolic performance in patients with Chagas' disease is presented.

UNITERMS: Chagas' disease. Ventricular function.

\section{INTRODUCTION}

$\mathrm{C}$ hronic Chagas' heart disease is certainly the most important clinical form of Chagas'disease. The chronic cardiac involvement of this disease is more prevalent, and it is also associated to larger morbidity and mortality, when compared to digestive disease (megaesophagus and megacolon) (14,18). Dias (1985), in a longitudinal study, described, since the acute infection, a progressive increase in the proportion of patients with

\author{
Address for correspondence: \\ Benedito Carlos Maciel \\ Divisāo de Cardiologia, Departamento de Clínica Médica \\ Faculdade de Medicina de Ribeirão Preto \\ Universidade de São Paulo \\ Ribeirão Preto - SP - Brasil - CEP 14049-900
}

cardiac disease from the second $(33.8 \%)$, to third $(49.3 \%)$ and fourth $(58.1 \%)$ decades of follow up. The progression of cardiac involvement is, however, heterogeneous, and tend to be slow: about $70 \%$ of cardiac subjects who have mild cardiac involvement, without heart failure, remain clinically stable for periods ranging from 12 to 27 years of follow up(1). The basic mechanisms determining the progression of heart disease in each chagasic patient remain unknown. There are, however, evidences suggesting that the prognosis of patients with chronic Chagas' heart disease depends on the clinical expression of heart involvement. Baseline electrocardiographic abnormalities (29), cardiac arrhythmias (14) and left ventricular function (4) are recognized as important risk factors for increased mortality in those patients.

The most important histological findings in chronic Chagas' heart disease are: chronic diffuse myocarditis, interstitial fibrosis, myocardial fiber hypertrophy with or without focal atrophy and myocytolisis $(22,33)$. A large 
number of patients present focal thinning of the myocardium or aneurysm at the left ventricular apical region. Clinical manifestations of the chronic cardiac fase of the disease are quite variable: patients can be asymptomatic or may present different types of arrhythmias (including potentially lethal ventricular arrhythmias), atrioventricular block, conduction abnormalities on electrocardiogram or heart failure. The clinical picture of heart failure due to extensive myocardial damage mimics that of idiopathic dilated cardiomyopathy (35). Left ventricular dysfunction, left ventricular aneurysm and congestive heart failure are recognized as important predictors of mortality in those patients. In addition, left ventricular systolic dysfunction appears to be significantly correlated with complex ventricular arrhythmias (10) and also with conduction abnormalities on the electrocardiogram (11).

Most of the invasive or noninvasive methods used so far to evaluate systolic ventricular function in Chagas' disease have analysed overall performance of the ventricles, reflecting the interaction of preload, afterload, contractility and heart rate (5). Hemodynamic studies of patients with the chronic cardiac form have shown data comparable to that observed in dilated idiopathic cardiomyopathy, including: increased pulmonary artery and pulmonary wedge pressures and also high end-diastolic ventricular pressures; increased right and/or left ventricular volumes and reduced ventricular ejection fraction (41). The magnitude of these changes is quite variable depending on the degree of myocardial involvement in each patient. Segmental left ventricular wall motion analysis based on echocardiography and radionuclide or contrast angiography have shown a number of abnormalities in chronic cardiac chagasic patients $(1,2,4,9,41)$ : apical dyskinesia was documented in 50-65\% of symptomatic cardiac patients, while akinesia or hypokinesia were observed in the same region in aproximately $20 \%$ of patients (Figure 1); on the other hand, wall motion abnormalities involving postero-inferior wall are reported in $15-20 \%$ of patients and rarely at lateral wall; finally, diffuse left ventricular hypokinesia was observed in $15-40 \%$ of patients. It is important to mention that, in a significant proportion $(31 \%)$ of chronic cardiac patients, segmental wall motion abnormalities in more than one region has been documented (4). It is also relevant that this variable pattern of segmental involvement of the heart is not related to obstructive lesions at epicardial coronary arteries, which are usually normal or even dilated in chagasic patients. The analysis of right ventricular function in chronic Chagas' heart disease has been relatively neglected so far. Marin-Neto et al. (30) have shown an important impairment of right ventricular systolic function in this clinical setting, ocurring even in those patients with normal overall left ventricular function and without any clinical evidence of heart disease (Figures 2 and 3). Right ventricular aneurysms have been reported

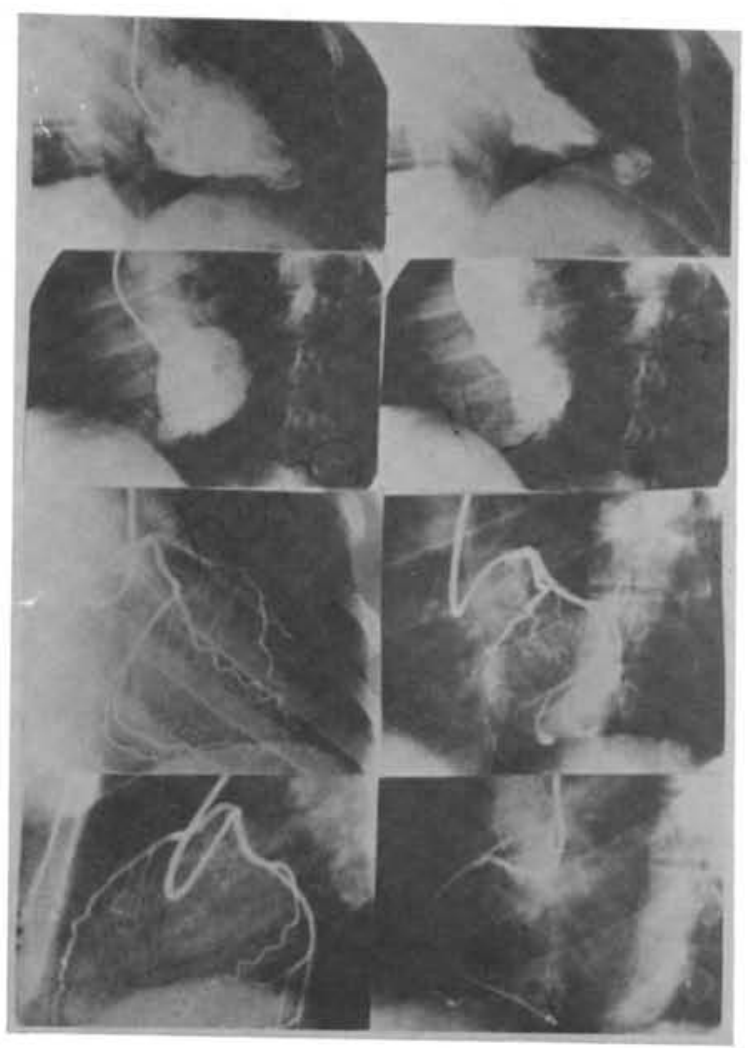

Figure 1. End-diastolic and end-systolic left ventricular angiographic frames in a patient with chronic Chagas' heart disease showing apical aneurysm and inferior dyskinesia. In the lower half of the figure normal coronary arteries are shown.

in $10 \%$ of chronic chagasic patients evaluated by echocardiography (1).

The indeterminate form of Chagas' disease has been extensively investigated recently to determine whether or not there are evidences, in these patients, of any degree of digestive or myocardial involvement. Patients are included in this clinical form when they have a positive serological test for Chagas' disease, no symptoms and normal electrocardiogram and x-ray examination of heart, esophagus and colon (39). Different diagnostic techniques used to study patients with the chronic indeterminate form of Chagas' disease have shown some degree of impairment of digestive or heart function, but the results of those investigations needed to be critically reviewed: the criteria for including patients in the indeterminate form and for analysis of electrocardiogram results were not 


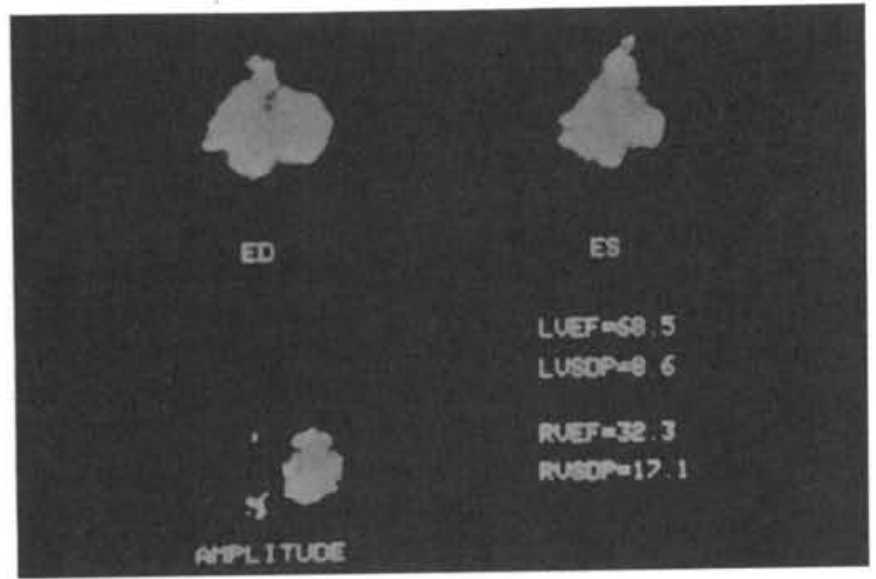

Figure 2. End-diastolic and end-systolic images of radionuclide angiogram in an asymptomatic chagasic patient showing isolated impairment of right ventricular systolic function.

homogeneous; in some studies, a control group was not included $(16,36,42)$. Depending on the diagnostic method utilized, a variable proportion of abnormalities of heart function has been reported. Therefore, abnormalities were described in $68-88 \%$ of patients $(26,38)$ studied by vectocardiography; $73 \%$ of patients had an exercise stress test considered abnormal (38); abnormal myocardial 99m technetium-pyrophosphate uptake was found in $82 \%$ of patients; Holter monitoring was reported abnormal in 42 $50 \%$ of cases $(27,38)$; atrial dromotropic abnormalities during electrophysiologic studies were observed in $50 \%$ of patients (17) and in $61 \%$ of cases studied by endomyocardial biopsy an abnormal hystological pattern was documented. Pereira-Barreto et al. (38) have shown in a group of 22 patients with the chronic indeterminate form of Chagas' disease that all patients had at least one out of six diagnostics methods applied (vectocardiography, echocardiography, radionuclide ventriculography, myocardial uptake of $99 \mathrm{~m}$-technetium pyrophosphate, exercise stress test, Holter monitoring) considered as abnormal. The prognostic implications of these abnormalities to influence progress of the disease to the symptomatic clinical forms or regarding mortality are currently unknown.

Left ventricular systolic function has been evaluated in patients included in the indeterminate form of Chagas' disease using different methods. Studies with contrast ventriculography reported segmental left ventricular wall motion abnormalities in up to $50 \%$ of patients, including $25-37 \%$ of cases with apical akinesia or dyskinesia, 15$20 \%$ of patients with diffuse hypokinesia, $3.3 \%$ of cases

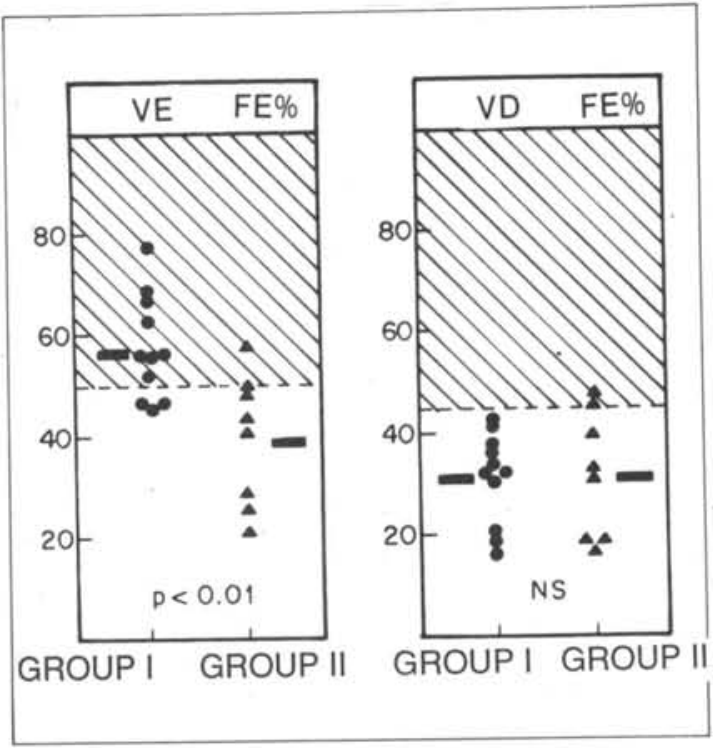

Figure 3. Radionuclide left and right ventricular ejection fraction in group 1 (noncardiac) and group 2 (cardiac) chagasic patients. Horizontal bar represent average values in each group. The hatched areas indicate the normal range (2 SD of mean).

with akinesia of anterior wall and $10 \%$ of patients with more than one segmental abnormality documented $(23,28,40)$. Those invasive studies have also shown an increased left ventricular end-diastolic pressure occurring in 40 to $100 \%$ of patients evaluated $(23,28,40)$. However, when comparing 23 patients with the indeterminate form and normal subjects, Mady et al. (24) described a minor but significant increase of right ventricular diastolic pressure in the chagasic group, as the only hemodynamic abnormality that distinguished normal subjects from the chagasic group. In addition, in this investigation (24) left ventricular apical dyskinesia was not documented by contrast ventriculography.

Discrepant observations have also been reported in studies using noninvasive methods of left ventricular function analysis. Left ventricular apical dyskinesia or akinesia have been observed in $10-40 \%$ of patients with indeterminate form evaluated by two-dimensional echocardiography $(1,2,38)$, while left ventricular posteroapical hypokinesia was the main abnormality reported by Ortiz et al. (34) (22\% of cases), who also found diffuse hypokinesia in $4 \%$ of the indeterminate chagasic patients. In studies using M-mode echocardiography, some investigators $(3,19,37)$ have reported mild increase of left ventricular diastolic dimensions and/or a minor impairment of left ventricular systolic function in indeterminate chagasic patients while other studies did not show any differences in those variables when comparing chagasic and normal subjects $(2,38,42)$. Left ventricular ejection fraction under resting conditions, as evaluated by radionuclide angiography, was not different when 
comparing normal and indeterminate patients $(21,31,38)$. On the other hand, left ventricular segmental wall motion analysis in these studies have shown apical hypokinesia in up to $68 \%$ of cases $(31,38)$ or even absence of any segmental wall motion abnormality (21). In a recent study (30), Marin-Neto et al. documented, in a group of 5 patients with the indeterminate form of Chagas' disease, that while the left ventricular ejection fraction was normal as evaluated by radionuclide ventriculography, right ventricular systolic function was significantly depressed, indicating that right ventricular dysfunction can be the only abnormality in this group of patients.

Sousa (42) investigated in our laboratory left ventricular systolic function by two-dimensional echocardiography during stress conditions. Fifteen patients rigorously classified in the indeterminate form of Chagas' disease were evaluated during isometric exercise and after administration of isosorbide dinitrate. Ejection phase indices of overall left ventricular systolic performance, as percent fractional shortening or velocity of left ventricular shortening, were comparable in normals and indeterminate patients under resting and stress conditions, but segmental quantitative wall motion analysis have shown a minor impairment of systolic funtion at the posterior wall in chagasic patients during isometric exercise, suggesting a reduced functional cardiovascular reserve in these patients. Furthermore, this study demonstrated that patients with the digestive form of Chagas' disease have a more important impairment of segmental left ventricular function during exercise as compared to indeterminate patients, suggesting that simultaneous digestive and cardiac involvement of this disease could be a frequent association. Similar results showing simultaneous digestive and cardiac involvement were published later by Moraes Filho et al. (32). Patients with digestive and indeterminate forms of Chagas' disease also had an improvement of left ventricular function after receiveing sublingual isosorbide dinitrate (42). This pattern of response was not observed in normal subjects, reinforcing the impression that these groups of chagasic patients had an impairment of functional cardiac reserve and, also, adverse basal conditions of preload and afterload.

Despite the discrepant observations published regarding myocardial involvement in patients with the indeterminate form of Chagas' disease, and even considering the limitations of some investigations related to inadequate clinical characterization of the indeterminate form, it should be recognized that a substantial proportion of these patients can have minor impairment of left ventricular systolic function. It is also important to mention that, according to the available data, patients with indeterminate form have an excelent longterm prognosis (18).

Quantitative evaluation of myocardial contractility, an intrinsic property of ventricular muscle fiber, is a quite complex and controversial issue. Overall left ventricular systolic performance depends on the beat-to-beat interaction of myocardial contractility, afterload, preload and heart rate. Traditional approaches to study left ventricular performance are unable to differentiate changes in contractility from modifications of the loading conditions or heart rate (5). This is an important limitation of ejection phase indices including percent fractional shortening, mean velocity of left ventricular fiber shortening, ejection fraction, stroke volume or cardiac output and also of left ventricular wall motion analysis. Isovolumic indices of left ventricular systolic performance, obtained during the pressure variation at the pre-ejection period, as the maximal rate of left ventricular pressure rise (dP/dt max), are sensitive to myocardial contractility but also depend on preload conditions.

Recently, several indices of left ventricular performance relating physiologic forces acting on the myocardium at end-systole have been shown to be sensitive to myocardial contractility and independent of loading conditions. Experimental studies have demonstrated that, as afterload increases, the extent of ventricular systolic fiber shortening falls, resulting in progressively greater end-systolic fiber length and ventricular dimensions. In addition, over the physiologic range, a linear relationship has been observed between left ventricular end-systolic dimension and afterload (43). The slope of the left ventricular end-systolic pressure-dimension (or volume) relation has been proposed in the clinical setting as a reliable index of contractility, considering that it is independent of preload, incorporates afterload and varies directly with modifications of the myocardial contractile state $(6,7,8)$. Another sensitive index of contractility related to the physiologic events at end-systole is obtained through the relationship between left ventricular end-systolic meridional wall stress and the rate-corrected velocity of fiber shortening (12). These indices have an additional advantage: they can be obtained noninvasively by changing afterload with vasoactive drugs and estimating end-systolic pressures using calibrated carotid pulse tracings while left ventricular end-systolic dimensions (or volumes) are measured using M-mode echocardiography.

Almeida-Filho et al. (1993, unpublished results) measured, in our laboratory, the slope of the left ventricular end-systolic pressure-dimension relationship in patients with the indeterminate, digestive and cardiac forms of Chagas' disease compared to a normal group of subjects. 
All patients had a normal overall left ventricular systolic performance as evaluated by two-dimensional echocardiography under resting conditions, despite the fact that some chagasic patients with different clinical forms had a minor segmental wall motion abnormality. Traditional indices of left ventricular systolic performance, as percent fractional shortening and mean velocity of fiber shortening, were not able to differentiate the three chagasic groups from normals both in baseline conditions and after intravenous phenylephrine administration. However, the slope of pressure-dimension relation was significantly lower in the three chagasic groups compared to the normal subjects (Figure 4). In addition, chagasic patients who had a baseline wall motion abnormality on two-dimensional echocardiogram had the lower indices of myocardial contractility for each chagasic group. These data indicated that the left ventricular end-systolic pressure-dimension relation is a sensitive index of contractility, useful for investigations in the chagasic population. These results also suggest that minor baseline left ventricular wall motion abnormality on echocardiographic study is a determining factor for lower overall contractility index, independent of the clinical form of Chagas' disease. The longterm prognostic value of this changes, however, remains to be determined.

Left ventricular diastolic function has not been extensively evaluated in Chagas' disease. Studies using computerized echocardiographic (M-mode) analysis of left ventricular wall motion $(13,42)$ or spectral Doppler $(15)$ obtained results indicating a left ventricular diastolic

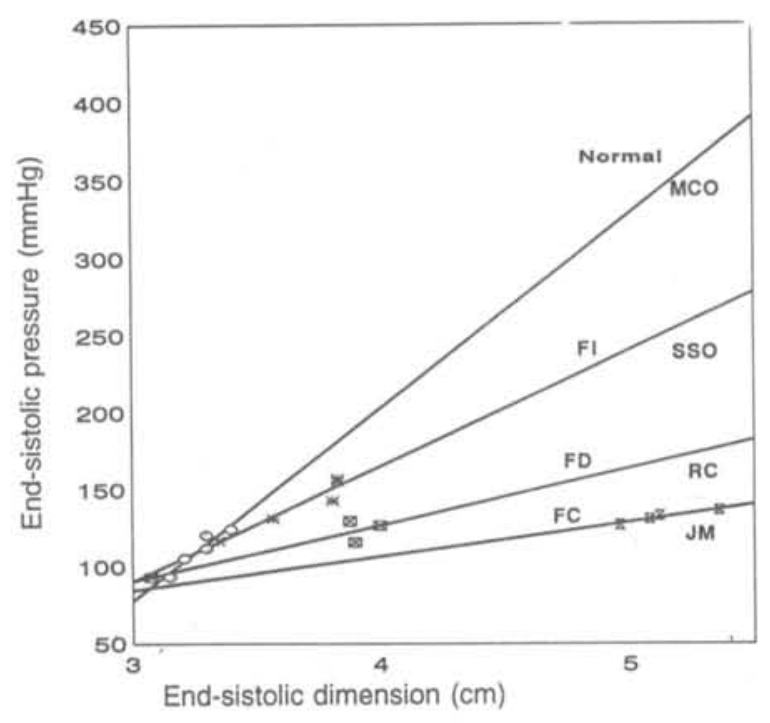

Figure 4. Linear regression analysis of left ventricular end-systolic pressure-dimension relationship in a normal subject and in patients with indeterminate, digestive and cardiac forms of Chagas' disease.

disfunction, even in patients with the indeterminate form of the disease. In addition, there are some data suggesting that the impairment of diastolic function occurs prior to left ventricular systolic disfunction in the natural history of Chagas' disease.

\section{RESUMO}

Uma ampla revisăo dos métodos invasivos e não invasivos utilizados na abordagem da função ventricular em diferentes formas clínicas da moléstia de Chagas é apresentada. A maior parte dos métodos empregados nesta avaliação exprimem o desempenho global dos ventrículos, refletindo a interação dos diversos determinantes do desempenho: pré-carga, contratilidade, pós-carga e freqüência cardíaca. Discute-se, ainda, o papel da função ventricular como determinante de mortalidade em cardiopatas chagásicos. Uma ênfase especial é dada à abordagem da funçāo ventricular em formas não cardiacas da moléstia de Chagas. Finalmente, sāo discutidas as evidências de comprometimento precoce da função diastólica ventricular esquerda na história natural desta doença. 


\section{REFERENCES}

1. ACQUATELla, H. \& SCHILleR, N.B. Echocardiographic recognition of Chagas' disease and endomyocardial fibrosis. J Am Soc Echo 1: 60-68, 1988.

2. ACQUATELLA, H.; SCHILLER, N.B.; PUIGBÓ, J.J. et al. - M-mode and Two-dimensional Echocardiography in Chronic Chagas' Heart Disease. A Clinical and Pathologic Study. Circulation 62: 787-799, 1980.

3. ALMEIDA, O.R.L.; BRITO, P.C.; SANTOS, C.R.L.; MARANHĀO, N.B.C.; ALVES, P.J. \& BARBARA, E.T. Ecocardiograma na doença de Chagas. Análise da função ventricular esquerda. Arq Bras Cardiol 37: 62, 1981.

4. ARREAZA, N.; PUIGBÓ, J.J.; ACQUATELLA, H. ET al. Radionuclide evaluation of left ventricular function in chronic Chagas' cardiomyopathy. J Nucl Med 24: 563-567, 1983.

5. BOROW, K.M. - An integrated approach to the noninvasive assessment of left ventricular systolic and diastolic performance. In: Sutton MST. ed. Textbook of Adult and Pediatric Echocardiography an Doppler. Blackwell Scientific Publications, 1989, p.97.

6. BOROW, K.M.; COME, P.C.; NEUMANN, A.; BAIM, D.S.; BRAUNWALD, E. \& GROSSMAN, W. - Physiologic Assessment of the Inotropic, Vasodilator and Afterload Reducting Effects of Milrinone in Subjects Without Cardiac Disease. Am J Cardiol 55: 1204-1209, 1985.

7. BOROW, K.M.; GREEN, L.H.; GROSSMAN, W. \& BRAUNWALD, E. - Left ventricular end-systolic stress-shortening and stress-length relations in humans. Am J Cardiol 50: 1301-1308, 1982.

8. BOROW, K.M.; NEUMANN, A. \& WYNNE, J. - Sensitivity of End-systolic Pressure-Dimension and Pressure-Volume Relations to the Inotropic State in Humans. Circulation 65: 988-997, 1982.

9. CARRASCO, H.A.; BARBOZA, J.S.; INGLESSIS, G.; FUENMAYOR, A. \& MOLINA, C. - Left ventricular cineangiography in Chagas' disease: detection of early myocardial damage. Am Heart J 104: 595-602, 1982.

10. CARRASCO, H.A.; GUERRERO, L.; PARADA, H.; MOLINA, C.; VEGAS, E. \& CHUECOS, R. - Ventricular arrhythmias and left ventricular myocardial function in chronic chagasic patients. Int J Cardiol 28: 35-41, 1990.

11. CASADO, J.; DAVILA, D.F.; DONIS, J.H. et al. Electrocardiographic abnormalities and left ventricular systolic function in Chagas' heart disease. Int $\mathrm{J}$ Cardiol 27: $55-62,1990$.

12. COLAN, S.D.; BOROW, K.M. \& NEUMANN, A. - The left ventricular end-systolic wall stress-velocity of fiber shortening relation. A load independent index of myocardial contractility. J Am Coll Cardiol 4: 715-724, 1984.

13. COMBELLAS, I.; PUIGBÓ, J.J.; ACQUATELLA, H.; TORTOLEDO, F. \& GOMEZ, J.R. - Echocardiographic features of impaired left ventricular diastolic function in Chagas's heart disease. Br Heart J 53: 298-309, 1985.
14. COURA, J.R. - Determinantes epidemiológicos da doença de Chagas no Brasil: a infecção, a doença e sua morbi-mortalidade. Mem Inst Oswaldo Cruz 83: 392-402, 1988.

15. CUNHA, C.L.P.; URBANETZ, L.A.G.T.; SOUZA, A.M. et al. - Evolutive Doppler echocardiographic changes in the indeterminate phase of Chagas' disease. Europ Heart J 14: 135, 1993.

16. DÉCOURT, L.V.; SOSA, E.A. \& MADY, C. - Forma indeterminada: conceito e aspectos fisiopatológicos. In: Cançado, J.R. \& Chuster, M. eds. Cardiopatia chagásica. Belo Horizonte, 1985. 121 p.

17. DÉCOURT, L.V.; SOSA, E.A. \& PILEGGI, F. - Estudos eletrofisiológicos cardíacos na forma indeterminada da doença de Chagas. Arq Bras Cardiol 36: 427-434, 1981.

18. DIAS, J.C.P. - História natural. In: Cançado, J.R. \& Chuster, M. eds. Cardiopatia chagásica. Belo Horizonte, 1985.99 p.

19. FRIEDMANN, A.A.; ARMELIN, E. \& LEME, L.E.G. Desempenho ventricular na doença de Chagas. Relações ecocardiográficas na miocardiopatia com distúrbio dromótropo e na fase pré-clínica. Arq Bras Cardiol 36:23-27, 1981.

20. HAGAR, J.M. \& RAHIMTOOLA, S.H. - Chagas'Heart Disease in the United States. N Engl J Med 325: 763-768, 1991.

21. KUSCHNIR, E.; SGAMMINI, H.; CASTRO, R.; EVEQUOZ, C.; LEDESMA, R. \& BRUNETTO, J. Valoracion de la función cardíaca por angiografia radioisotópica, en pacientes con cardiopatía chagásica crónica. Arq Bras Cardiol 45: 249-256, 1985.

22. LARANJA, F.S.; DIAS, E.; NÓBREGA, G. \& MIRANDA, A. - Chagas' disease: a clinical, epidemiologic and pathologic study. Circulation 14: 1035-1060, 1956.

23. LORGA, A.M.; GARZON, S.A.C. \& GRECO, O.T. Cardiopatia chagasica sem sinais clínicos de cardiopatia. Estudo cineangiocardiográfico e hemodinâmico. Arq Bras Cardiol 26: 54, 1973.

24. MADY, C.; MORAES, A.V.; GALIANO, N. \& DÉCOURT, L.V. - Estudo hemodinâmico na forma indeterminada da doença de Chagas. Arq Bras Cardiol 38:271-275, 1982.

25. MADY, C.; PEREIRA-BARRETO, A.C.; IANNI, B.M.; LOPES, E.A. \& PILEGGI, F. - Right ventricular endomyocardial biopsy in undetermined form of Chagas' disease. Angiology 35: 755, 1984

26. MADY, C.; PEREIRA-BARRETO, A.C.; MOFFA, P.J.; IANNI, B.M.; ARTEAGA-FERNANDEZ, E.; BELLOTI, G. \& PILLEGI, F. - O vetorcardiograma na forma indeterminada da doença de Chagas. Arq Bras Cardiol 44: 83, 1985.

27. MARINS, N.; FLORES, A.P.; SEIXAS, T.N. et al. Eletrocardiografia dinâmica em chagásicos na forma indeterminada ou sem cardiopatia aparente. Arq Bras Cardiol 39: 203, 1982.

28. MARINS, N.; SILVA, C.T.; MOTTA, V.P.; SCIANNI, C.C.P.; ARCALDI, N. \& MATOS, J.V. - Estudo hemodinâmico em indivíduos chagásicos sem cardiopatia. Arq Bras Cardiol 37: $463,1981$. 
29. MAGUIRE, J.H.; HOFF, R.; SHERLOCK, I. et al. - Cardiac morbidity and mortality due to Chagas' disease: prospective electrocardiographi study of a Brazilian community. Circulation 75: 1140-1145, 1987.

30. MARIN-NETO, J.A.; MARZULLO, P.; SOUSA, A.C.S. et al. - Radionuclide angiographic evidence for early predominant right ventricular involvement in patients with Chagas' disease. Can J Cardiol 4: 231-236, 1988.

31. MENEGUETTI, J.C.; PAPALÉO NETTO, M. \& DIAS NETO, A. - Estudo quantitativo da função ventricular de repouso e de exercício em pacientes chagásicos através de métodos radioisotópicos. Arq Bras Cardiol 37: 91, 1981.

32. MORAES-FILHO, J.P.P.; MORAES, T.A.B.P.P; FELIX, V.N.; PEREIRA-BARRETO, A.C. \& BETTARELLO, A. Esophageal manometry and vectorcardiography study of asymptomatic patients with Chagas' disease. Rev Inst Med Trop S P 30: 406-410, 1988.

33. OLIVEIRA, J.S.M.; OLIVEIRA, J.A.M.; FREDERIGUE JR., U. \& LIMA-FILHO, E.C. - Apical aneurysm of Chagas' heart disease. Br Heart J 46: 432-437, 1981.

34. ORTIZ, J.; PEREIRA-BARRETO, A.C.; MATSUMOTO, A.Y. et al. - Alteração contrátil segmentar na forma indeterminada da Doença de Chagas. Estudo ecocardiográfico. Arq Bras Cardiol 49: 217-220, 1987.

35. PARADA, H.; CARRASCO, H.A.; GUERRERO, L.; MOLINA, C.; CHECOS, R.; MARTÍNEZ, O. - Diferencias clínicas y paraclínicas entre la miocardiopatia chagásica crónica y las miocardiopatias dilatadas primarias. Arq Bras Cardiol 53: 99-104, 1989.

36. PEREIRA-BARRETO, A.C. \& AMATO NETO, V. Subsídios para nova conceituação da forma indeterminada da doença de Chagas. Rev Hosp Clin Fac Med S Paulo 41: 249-253, 1986.

37. PEREIRA-BARRETO, A.C.; ORTIZ, J.; MADY, C. et al. Estudo ecocardiográfico na forma indeterminada da doença de Chagas. Correlação com biópsia endocárdica. Arq Bras Cardiol 37: 168, 1981.

38. PEREIRA-BARRETO, A.C.; SERRO AZUL, L.G.; MADY, C. et al. - Forma indeterminada da Doença de Chagas. Uma doença polimórfica. Arq Bras Cardiol 55: 347-353, 1990.

39. I Reunião Anual de Pesquisa Aplicada em Doença de Chagas - Validade do conceito de forma indeterminada de doença de Chagas. Rev Soc Bras Med Trop 18: 46, 1985.

40. SAAD, E.A. - Estudos sobre a doença de Chagas. 1978 [Tese Professor Titular, Fac. Medicina UFRJ].

41. SAAD, E.A.; SALLES NETTO, M.; PRYZYTYK, R.N.; FERES, J.G.F.; SOUZA, E.A. \& ABRAÃO, C. - Estudo hemodinâmico e angiográfico. In: Cançado, J.R. \& Chuster, M. eds. Cardiopatia chagásica. Belo Horizonte, 1985. 188 p. 42. SOUSA, A.C.S. - Estudo da função sistólica e diastólica do ventrículo esquerdo de pacientes chagásicos nas formas indeterminadas, cardíaca crônica e digestiva, submetidos ao esforço isométrico contínuo e a ação de um vasodilatador sistêmico, por meio de ecocardiografia e da angiocardiografia nuclear. 1987 [Tese de doutoramento apresentada a Faculdade de Medicina de Ribeirão Preto da Universidade de São Paulo].

43. SUGA, H. \& SAGAWA, K. - Instantaneous pressure-volume relationships and their ratio in the excised, supported canine left ventricle. Circ Res 35: 117, 1974. 